\title{
Reflections on student-centered learning: An alternative to traditional English classes ${ }^{1}$
}

\section{Reflexiones sobre el enfoque centrado en el estudiante: Una alternativa para las clases tradicionales de inglés}

\author{
Sulma Patricia Fonseca Cely ${ }^{2}$ \\ Colegio Simón Bolivar de Soracá - Soracá \\ pattyfonce@yahoo.es \\ Leidy Girleza Cano García ${ }^{3}$ \\ Universidad Pedagógica y Tecnológica de Colombia - Tunja \\ leidy.cano@uptc.edu.co
}

Received: October 24, 2016

Accepted: January 20, 2017

How to cite this article (APA, 6th ed.): Fonseca-Cely, S., and Cano-García, L. (2017). Reflections on student-centered learning: An alternative to traditional English classes. Enletawa Journal, 10 (1), 87 - 96

\footnotetext{
Abstract

This article presents some methodological reflections about student-centered learning in order to achieve the Colombian National Standards for Bilingual Education in English classes in an elementary school context. It also discusses the need to raise teacher awareness, understanding of these methodologies, and the need to change teachers' beliefs and behaviors in the classroom. Findings show that student-centered learning is an alternative for teachers, and it should be included in schools' Proyecto

1 Reflective Article

2 Sulma Patricia Fonseca Cely holds a B.A in Modern Languages and is a full-time teacher at Colegio Simón Bolivar de Soracá. She is an M.A candidate in Language Teaching at Universidad Pedagógica y Tecnológica de Colombia.

3 Leidy Girleza Cano García holds a B.A in Foreign Languages Education from Universidad Pedagógica y Tecnológica de Colombia and is an assistant professor at Universidad Pedagógica y Tecnológica de Colombia. She belongs to the research group "JOIE".
} 
Educativo Institucional (PEI) in order to achieve bilingualism. Furthermore, it allows students to explore, practice and increase their autonomy and self-confidence in using a foreign language.

Key words: student-centered, English as a foreign language, education policy.

\section{Resumen}

Este artículo presenta algunas reflexiones metodológicas sobre el enfoque centrado en el estudiante para lograr los Estándares Nacionales de Educación Bilingüe en las clases de inglés en una escuela primaria. También se analiza la necesidad de aumentar la conciencia y la comprensión de los maestros de estas metodologías, las creencias y los comportamientos de los docentes que se requieren para cambiar en el aula. Igualmente, presentó los hallazgos que revelaron que el enfoque centrado en el estudiante es una alternativa para los maestros en las clases y los colegios necesitan incluirlo en el Proyecto Educativo Institucional (PEI) para alcanzar el bilingüismo. Así mismo, permite a los estudiantes explorar, practicar y aumentar su autonomía y confianza en sí mismos utilizando el idioma extranjero.

Palabras clave: aprendizaje centrado en el estudiante, inglés como lengua extranjera, políticas educativas. 


\section{Introduction}

The achievement of a high level of English proficiency proposed by the Ministry of Education of Colombia entails the analysis of the teaching practices and conditions in which those practices are carried out. Most schools provide more emphasis on teacher-centered learning rather than student-centered learning. In this paper, we reflect upon the importance of implementing student-centered learning in the classroom in order to increase the English language level of students in elementary classes in a public institution.

\section{Literature Review}

\section{Importance of English}

People who learn English as a foreign language have the opportunity to interact with people from other countries and access betterjobs and education. According to the Estándares Básicos en Competencias en Lenguas Extrajeras: Inglés (Basic Standards of Competences in Foreign Languages: English, National Ministry of Education, 2006), being competent in a foreign language is essential in a globalized world because it opens frontiers, lets people understand contexts and helps them be more understood. Being bilingual broadens the opportunities to be more competent and competitive. All these opportunities help Colombian citizens ensure a better quality of life. With this plan, Colombia seeks to develop citizens who are able to communicate in a foreign language (English) with international standards according to the Ministry of
Education (2005a). For example, we have noticed that translation jobs in our country are highly well-paid. Bilingual employees have a higher success rate in finding jobs. Moreover, being bilingual allows our students to study in other countries and have a wider understanding of the research being conducted internationally.

Cárdenas (2006) argues that in Colombia there are few opportunities and settings to use English as a foreign language and that the main purpose of learning a foreign language is for academic purposes. One example is the Saber test (prueba Saber Pro), a national test required to receive a university degree. Moreover, Herazo Rivera, Jerez, \& Lorduy Arellano (2012) explain that there are some jobs that require the use and knowledge of English as a foreign language, but students who graduate from public schools have fewer opportunities to access these jobs. In Colombia, there are some vendors who speak some English at markets and in other tourist areas for commercial purposes, but "the proportion of educated people who still do not speak English (confidently) is too high to be overlooked" (Mufwene, 2010 p. 46). Colombia has to guarantee that its students have the same opportunities to access jobs where English is required, such as coordinator, secretary, museum guide, interpreter, and others.

Cooper (1989) mentioned that in order to provide access to the language, it is necessary to create conditions for language learning to occur in any place. All Colombian citizens must be provided with the same tools that let them compete 
under the same conditions. The Ministry of Education needs to make changes to provide all its citizens with the same opportunities to learn a foreign language. Improvements can be made in the number of hours for English language instruction in elementary schools, where there are resource-shortages and overcrowded classrooms. These classrooms have a large diversity of students, with as much as six different grade levels in the same room. Colombian schools need all these changes to provide better possibilities for teaching, learning, and achieving governmental goals.

Colombia must focus on studentcentered learning in elementary schools in order to create bilingual citizens. Using a student-centered approach, the learning process is more reflexive, and students can increase their responsibility and autonomy. According to Lorenz (1965), in order to learn a language, it is necessary to have an enjoyable time doing so. There is a developmental period in childhood when key experiences have a greater effect on learning. Moyer (1999) suggested that during childhood, first language and phonological matrices are still in formation. So, children are able to identify and differentiate both native and foreign language sound systems.

\section{Education policy in Colombia}

Colombia created the National Bilingual Program in 2004. This program was meant to be developed from 20042019. It searched to provide people with English knowledge, as well the vision to increase productivity and foster national intercultural awareness and openness. In 2010, The Program for Strengthening the Development of Competences in Foreign Languages was launched by the Ministry of Education. According to the Ministry of Education (2014a, 2016b), this program gave continuity to activities and strategies proposed in the National Bilingual Program. Other aspects of improvement, such as teacher training and professional development, were added. This program also provided elementary, middle, and high school English teachers from public institutions with more possibilities of participating in immersions programs.

In 2006, the government also introduced the Estándares Básicos en competencias en Lenguas Extranjeras: Inglés (National Ministry of Education, 2006). This translates to the BasicStandards in Foreign Language Skills: English. These are a set of basic standards that an English teacher should follow with their students and thus guarantee that their students will achieve a high level of proficiency. These standards were adapted from Europe and used in Colombia according to "Al tablero" (October 2005).

In 2014, the Ministry of Education (2014b) created the National Plan of English called Colombia Very Well 2015-2025. This program was created to give continuity to strengthening the Development of Competences in Foreign Languages and the National Bilingual Program. One of the goals is to provide institutions with tools and technology for English teaching. Gómez (2017) suggested that the strategies implemented in the Program for Strengthening the Development of 
Competences in Foreign Languages were positive, but the results obtained were limited. In the same year, the program Bilingual Colombia 2014-2018 was created. According to Bonilla \& Tejada (2016), this program emerged six months later after the implementation of the program Colombia Very Well.

\section{Student-centered}

New approaches for learning languages are focused on students rather than teachers. In this paper, we use a studentcentered learning approach because we wanted to focus on students rather than on the teachers. Thornburg (as cited in Abel \& Campbell 2009, p. 4) defined student-centered learning as "an approach that involves the interaction of students and their instructor to create learning experiences that are applicable to the real world." According to Çubukçu (2012), it "is a model which puts the student in the center of the learning process. Student-centered learning is a model in which students play an active role in their own learning styles and learning strategies" (p. 50). Likewise, Lea,Stephenson \& Troy (ascited in Bremner, 2015) pointed out a series of characteristics of student-centered learning:

Reliance upon active rather than passive learning, an emphasis on deep learning and understanding, increased responsibility and accountability on the part of the student, an increased sense of autonomy in the learner, an interdependence between teacher and learner, mutual respect within the learner-teacher relationship, and a reflexive approach to the learning and teaching process on the part of both teachers and learner (p. 3).
In other words, students are immersed in an independent environment where they interact with learning styles which let them acquire knowledge. Therefore, the purpose of learning a foreign language with a student-centered learning approach is to explore students' ideas through activities that engage them to learn on their own.

Student-centered learning promotes many advantages for students. First, students determine their own goals, accomplish them through academic activities of their interest, while relearning from reallife and authentic experiences (Jonassen, as cited in Çubukçu, 2012, p. 51). Students are encouraged throughout their process. They reflect on their own learning process and share their insights with their peers. Furthermore, students can more easily grasp concepts because they are based on experiential learning (Lont, as cited in Çubukçu, 2012, p. 51). In this type of learning environment, students are required to analyze, synthesize and produce different kinds of knowledge. Kolb (as cited in Çubukçu, 2012, p. 51) explained that students learn by doing. In other words, students study on their own, and they determine what, how, and how long to study.

\section{Approaches related to Student- centered learning}

According to Bremner (2015), there are approaches that promote studentcentered learning and facilitate practicing language in a more authentic way. He highlighted that student-centered learning prioritizes a different focus 
in the classroom. This means "to shift their priorities from a sole focus on accuracy (i.e., correctly producing the linguistic forms) towards fluency and the appropriateness of what learners are able to communicate" (Bremner, 2015, p. 5). In this sense we as teachers can contribute to achieving The National Standards for Bilingual Education, as well as promoting a favorableenvironment in which students feel safe, joyful, and engaged. In addition, students have a sense of belonging, which leads to more academic engagement.

The following paragraphs present some specific approaches that are more consistent with the general aims of student-centered learning. Student-centered learning focuses on the use of the language for students' interactions and communication. This is a relationship between student and knowledge in order to make sense of real-life situations. The following approaches guide the student in different ways, but with the same underlying purpose: to use the language for communication in an autonomous environment. Wechoose the most relevant examples related to our research.

Collaborative learning. According to Contreras \& Chapetón (in press), the basis for this approach is constructivism, meaning that knowledge is constructed and transformed by students. This is because the students learn more through experience and active involvement than by listening and observing. Interacting with others is the central process in order to build knowledge.
Inquiry-based learning. This approach is focused on learning based on inquiry.

Task-Based Learning. This approach focuses on interaction rather than the formation of language throughout the development of tasks. In this sense, students are the central component of this learning process.

Content and Language Integrated Learning (CLIL). The principle of this approach is to use language to communicate. CLIL is the combination of content, communication, cognition and culture.

Bremner (2015) explains that there are other approaches that use student-centered learning, such as: Communicative Language Teaching, Communicative Functions of Language, Fluency and Communicative Competence, Authentic Content, and Inductive Reasoning. It is important to explore these approaches and choose the best one that fits the context and students' needs.

\section{Teachers' beliefs and practices in the classroom}

Teachers need to be aware of changes and look for the best way to promote student-centered learning in their practices. This "implies not only a change in teachers' behaviors, but also a transformation in their fundamental beliefs about education" (Bremner 2015, p. 5). Fullan (2007), Altinyelken (2010), and Schweisfurth (2013) stated that this is one of the educative changes that need to 
happen for success in language learning. Teacher's beliefs will affect the reality that they face in their classrooms, how they perceive the educational change, and how they promote new challenges in the classroom. Consequently, teachers need to start the process of training themselves.

For those changes, teachers are required to present solutions to problems and promote "increased motivation to learn, greater retention of knowledge, deeper understanding, and more positive attitudes toward the subject being taught" (Felder and Brent, as cited in Wedell, 2009, p. 18). On one hand, teachers need to be constantly training, not only in the proficiency of the foreign language, but also in its pedagogical and investigative aspects. Research plays an important role in teachers' training because this allows them to refresh and share ideas with colleagues and researchers around the world. This encourages teachers' opinions and beliefs about their practices, classroom implementations, and evaluation of the processes in their classes. At the same time, it helps to create new methodologies to foster the learning and teaching of a foreign language.

It is necessary to talk about the barriers that hinder this process in the Colombian context because they are out of the teacher's control. Wedell (as cited in Bremner 2015, p. 6) refers to "partners" as those who are responsible for the creation of the Proyecto Educativo Intitucional (PEI = Institutional Educational Project), which affect or strengthen the vision of the school.

Based on Bremner (2015), we looked at the most relevant barriers related to our context. These are the relationship between the educational institution's methodology and student-centered approaches in English as a foreign language (EFL) learning, classroom management, and the system of quality control for schools.

The first is the relationship between theschools' approachandstudent-centered EFL learning. Bremner (2015) stated that: "The Head of School asks the teacher to use a particular textbook and to cover a certain number of units per semester. However, the pedagogical approach of the textbook is not consistent with the aims of studentcentered EFL learning." (p. 7) In this sense, opposing teacher and administrative objectives do not allow for proper focus on enhancing the students' English level. School officials impose regulations that do not fit the context of each school, and teachers feel added pressure because schools demand proficient test results to achieve national goals and standards.

Likewise, the following statement revealed another important limitation in the implementation of student-centered learning, that of discipline. Bremner (2015) pointed out: "the teacher's colleagues (teachers of other subjects) complain that there is a lot of noise coming from the classroom during communicative tasks. The Head of School asks the English teacher to maintain more discipline in their class" (p. 7). Some schools may want to keep the students in their seats without any participation, but implementing student-centered learning requires the use of different approaches that let students explore. On the other hand, it is important that teachers implement research in 
their classroom. This implementation helps to improve the focus on studentcentered learning, and it provides a better understanding about the methodologies that fit best with students and their education.

Another important issue that is found in most schools in Colombia is the quality control system. Many schools are required to fill administrative documents, and teachers do not have the time to plan and change their methods. Even though this system helps schools be more organized, although it becomes a challenge when administrative paperwork is changing the teachers' role in the classroom to a bureaucratic one.

We need to raise teachers' awareness because they have the power to change the administrative system and the vision of the school. Teachers need to understand that "student-centered learning implies a change in the role of the students towards more reflective, autonomous human beings who are responsible for their own learning and are less dependent on the teacher to solve all of their problems" (Bremmer 2015, p. 9). Being conscious of these approaches allow teachers to enjoy their professions and witness how their students' can grow stronger and able to face any English language challenge in their lives.

\section{Conclusions}

It is possible to say that studentcentered experiences allow students to explore, practice, and increase their autonomy and self-confidence when using a foreign language. Students have to think and develop activities on their own. The role of the learner is being attentive and explorative in order to have real contact with the language.

Thereare two pedagogicalimplications to analyze. First, in Colombia the number of students per classroom is excessive. Both private and public schools can have over 30 students in the same room. It is sometimes difficult to develop all the activities in the classroom, and teachers have to look for alternative teaching spaces.

During implementation, teachers have observed that students seemed to enjoy lessons that included multisensory activities. We noticed that when students work using student-centered learning, they handle responsibility, show more tolerance, and try to work cooperatively. Yet, they are limited by a lack of resources. Both students and teachers require the use of technology, such as videos, TVs, and photocopiers, but many schools do not have this equipment, especially in rural places. It is necessary that the government provide institutions with more materials that help teachers and students in the process of teaching and learning, taking into account that there is more than one grade level in each classroom.

\section{References}

Abel, E. M., and Campbell, M. (2009). Student-centered learning in an advanced social work practice course: Outcomes of a mixed methos investigation. Journal Social Work Education, 28(1), 3-17. 
Al tablero. (2005 October - December). Retrieved from https://wwwmin educacion.gov.co/1621/propertyval ue-32266.html

Altinyelken, H. (2010). Curriculum change in Ugando: Teacher perspectives on the new thematic curriculum. International Journal of Educational Development, 30 (2), 151-161.

Bonilla Carvajal, C. A., and Tejada Sanchez, I. (2016). Unanswered questions in Colombia's foreign language education policy. PROFILE Issues in Teachers'Profesional Development, 18(1), 185-201.

Bremner, N. (2015). Reculturing Teachers as Just the Tip of the Icerbg: ongoing Challenges for the implementation of Student-centered EFL learning in Mexico. MEXTESOL, 39(3).

Cárdenas, M. (2006). Retos del Programa Nacional de Bilingüismo. Retrieved from: https://www.academia.edu/25 75639/Retosdel Programa NacionaldeBiling\%C3\%BCismo._Colombia_ Biling\%C3\%BCe

Contreras Leon, J. J., and Chapeton Castro, C. M. (in press). Transforming EFL classroom practices and promoting student's empowerment: Collaborative learning from a dialogical approach. PROFILE Issues in Teachers' Professional Development, 19(2).

Cubukçu, Z. (2012). Teachers' evaluation of student-centered learning environments. Education, 1, 49-66.

Fullan, M. G. (2007). The new meaning of educational change. London: Cassell.
Gómez Sará, M. M. (2017). Review and analysis of the Colombian foreign Language bilingualism policies and plans. HOW, 24 (1), 139-156.

Grosjean, F. (2010). Bilingual: life and reality. London: Harvard University.

Herazo Rivera, J. D., Jerez, R. S., and Lorduy Arellano, D. (2012). Opportunity and incentive for becoming bilingual in Colombia; implicatons for programa nacional de bilingüismo. íkala, Revista de Lenguaje y Cultura, 17(2), 199-213.

Lorenz, K. (1965). Evolution and modification of behavior. Chicago. University of Chicago Press.

Ministerio de Educación Nacional de Colombia. El programa nacional de bilingüismo (2004). Retrieved from http://www. mineducacion.gov.co

Ministerio de Educación Nacional de Colombia. Bases para una nación bilingüe y competitiva. (2005). Retrieved from http:// www.mineducacion.gov.co/1621/ propertyvalue-32266.html

Ministerio de Educación Nacional de Colombia. Estándares Básicos de Competencias en Lengua Extranjera: Inglés. Formaren lenguas extranjeras: inglés. (2006). Santafé de Bogotá: Imprenta Nacional.

Ministerio de Educación Nacional (2014a). Orientaciones para la implementación de proyectos de fortalecimiento del inglés en las entidades territoriales. Bogotá. Retrieved from http://www.colombiaaprende. edu.co/html/micrositios/1752/ articles-315518recurso5.pdf 
Ministerio de Educación Nacional, (2014b). Colombia very well! Programa Nacional de inglés 20015-2025 (Documento de socialización). Bogotá. Retrieved from http://www.colombiaaprende.edu. $\mathrm{co} / \mathrm{html} /$ micrositios/1752/articles343287recurso1.pdf

Moyer, A. (1999). Ultimate attainment in L2 phonology. The critical factors of age, motivation and instruction. Studies in Second Language Adquisition, 21(1), 81-108.

Mufwene, S. S. (2010). Globalization, global English and world English: Myths and facts. En N. Coupland (Ed.), The handbook of language and globalization (pp. 31-55). Malden: WileyBlackwell.

Programa Nacional de Inglés 2015 - 2025 'Colombia, very well'. Archivo de la presidencia. (2014, August 2). Retrieved from http://wsp.presidencia.gov.co/ Prensa/2014/Julio/

Paginas/20140710_05-ProgramaNacional-de-Ingles-2015-2025Colombia-very-well-pondra-a-hablaringles-a-los-colombianos.aspx

Sayer, P. (2015). "More \& Earlier": Neoliberalism and Primary English Education in Mexican Public Schools. L2 Journal, 40-56.

Schweisfurth, M. (2013). Learner-centered education in international perspective: whose pedagogy for whose development? London: Routledge.
Wedell, M. (2009). Planing educational change: putting people and their context first. London: Continuum. 